Article

\title{
Medium and Long-Term Returns to Professional Education in Switzerland: Explaining Differences between Occupational Fields
}

\author{
Fabian Sander * and Irene Kriesi \\ Swiss Federal Institute for Vocational Education and Training, 3052 Zollikofen, Switzerland; \\ E-Mails: fabian.sander@ehb.swiss (F.S.), irene.kriesi@ehb.swiss (I.K.) \\ * Corresponding author
}

Submitted: 28 February 2019 | Accepted: 3 June 2019 | Published: 5 September 2019

\begin{abstract}
In Switzerland, initial vocational education and training graduates may enter a track of the tertiary system called professional education. Professional education represents about one-third of the tertiary system, includes numerous vocational training courses, and prepares for managerial or expert positions. Despite its prevalence, the long-term returns to professional education have rarely been investigated due to lacking data. In order to fill this gap, we will estimate the long-term returns to professional education based on a novel methodological design. Secondly, we aim to explain the differences in the returns to professional education between occupational fields by making use of the task-based approach of Autor, Levy and Murnane (2003). Analyses are based on the Swiss Labour Force Survey from 1991-2016. Based on a quasi-panel with cohort fixed effects and on linear regression models, our results reveal average short-term returns to professional education of $7 \%$ and long-term returns of $11 \%$. However, we find considerable differences in the returns between training fields, which can partly be attributed to differences in the change of task composition after completion of professional education between occupations.
\end{abstract}

\section{Keywords}

initial vocational education and training; professional education; returns to education; work tasks

\section{Issue}

This article is part of the issue "Types of Education, Achievement and Labour Market Integration over the Life Course", edited by Irene Kriesi (Swiss Federal Institute for Vocational Education and Training, Switzerland) and Juerg Schweri (Swiss Federal Institute for Vocational Education and Training, Switzerland).

(C) 2019 by the authors; licensee Cogitatio (Lisbon, Portugal). This article is licensed under a Creative Commons Attribution 4.0 International License (CC BY).

\section{Introduction}

In Switzerland, one-third of all tertiary-level students complete a vocationally oriented track of higher education, called professional education. It is the main avenue to higher education from initial vocational education and training (IVET), which is the dominant form of upper-secondary education in Switzerland and chosen by about two-thirds of a birth cohort. Professional education reflects the strong occupational segmentation of the Swiss labour market and offers about 840 different occupation-specific training courses. They are accessible without a general university admissions certificate, also called baccalaureate, but usually require the previous completion of an upper-secondary degree and some work experience. The curricula are designed in collaboration with professional organisations and incorporate the skill requirements of specific occupations. Consequently, professional education provides in-depth vocational knowledge and also prepares for managerial positions. Depending on the professional education track, graduates receive diplomas called "College of Higher Education Diploma" or (Advanced) "Federal Diploma of Higher Education", which can be earned after full or parttime studies (Cattaneo \& Wolter, 2011; SBFI, 2018).

Despite the prevalence of professional education, little is known about the specific returns to this type of education. This holds for Switzerland as well as for 
other countries with comparable types of vocationally oriented higher education. The handful of existing studies shows a fairly large variation in returns between countries. A comparative descriptive analysis calculated an OECD average of $22 \%$ higher relative earnings compared with upper secondary or post-secondary non-tertiary education (OECD, 2011). Other studies report short-term returns of up to $25 \%$ for the US (Celeste \& Sanford, 2018; Jepsen, Troske, \& Coomes, 2012; and 33\% for Finland (Böckerman, Haapanen, \& Jepsen, 2018), compared to the wage before graduation. For Germany, Stüber (2016) estimates that lifetime incomes with professional education are $40 \%$ higher than with IVET but $15 \%$ lower compared to a university degree. The latter finding corresponds with the results of Brunello and Rocco (2015), who calculate $18 \%$ lower relative earnings in OECD countries for professional education holders compared to academic higher education.

For Switzerland, recent evidence shows that $60 \%$ of professional education diploma holders report positive wage effects one year after the exam (BFS, 2019). Descriptive figures reveal that, on average, workers with an IVET diploma earn about $27 \%$ less than workers with professional education (Baumeler, Kriesi, \& Barabasch, 2017). However, previous studies calculating short-term returns of professional education compared to IVET report varying figures, ranging between $19 \%$ and $37 \%$ (Sheldon, 1992; Weber, 1998; Wolter, 1994; Wolter \& Weber, 1999). A more recent study of Cattaneo (2011) estimates short-term returns of about $7 \%$, using fiveyear panel data. Based on the same data, and assuming stable economic and individual wage development, the study estimates prospective lifetime returns to professional education between $-4 \%$ and $+29 \%$, depending on the cost scenario.

In sum, the findings from previous national and international research are fairly heterogeneous and difficult to generalise because returns to education always depend on the national labour market structure and the educational composition of a country's working population. Furthermore, the findings are based either on the inconsistent use of international classification codes for education or refer to different points in time and/or different birth cohorts. Other shortcomings are that the existing studies report either causal estimates of short-term returns or non-causal estimates of long-term returns. However, economic downturns or changing values of certain skill sets are likely to influence educational long-term effects. The previous findings might therefore not be reliable (Bassanini, Booth, Brunello, De Paola, \& Leuven, 2007). Previous research does also not take into account that professional education is occupation-specific and thus very heterogeneous regarding the taught skill sets. Considering that skills are related to wage levels (Lemieux, 2015; Parent, 2000; Sullivan, 2010; Weeden, 2002; Williams, 2017), wage gains may differ between occupations after completion of professional education.
Against this background, our article estimates the average long-term returns to professional education compared to the time before graduation, when workers held an upper-secondary vocational training certificate only. We propose a novel methodological approach, which combines a quasi-experimental design with a quasipanel, using a fixed effects estimator. Furthermore, we investigate differences in the returns to professional education between occupational groups and analyse the role of occupation-specific working tasks in explaining these differences. Put differently, we ask three related research questions: 1 ) how high are the average longterm wage gains after completing professional education compared to the time before graduation? 2) Do the wage gains differ between occupation-specific types of professional education? 3) To what extent can earning differences be explained by a change in the task sets after completion of professional education? In the next section, we will outline our theoretical assumptions, which are based on human capital theory (Becker, 1962), and the task approach of Autor, Levy and Murnane (2003). The third section describes the methods and data. The results are presented in Section 4 and discussed in section 5 .

\section{Socio-Economic Perspectives of Returns to Professional Education}

Individual long-term returns to education are defined as the income benefits of continuing education minus its lifetime costs (Oreopoulos, 1972). Returns have been conceptualised either by comparing the income of people with and without a specific course of education or as the individual difference in income before and after completing extra education. While the first concept allows insights into return differences between different types of education, the second concept focuses on the wage gains of individuals after investing in more education. In this article, we focus on the second concept.

The economic and sociological wage literature assumes that returns to education depend on the interplay of supply and demand factors (Autor \& Handel, 2013; Oreopoulos, 1972). Whereas the supply depends on the skills of employees (Becker, 1962), demand factors may be related, for example, to company structure (Baron \& Bielby, 1980), employment relations (Goldthorpe, 2000), workplace authority (Wright, 2000), occupational gender-compositions (Murphy \& Oesch, 2016) or occupation-specific skill requirements (Tåhlin, 2007), and a changing economic structure (Autor et al., 2003).

Explanations of how individual skills determine longterm returns mainly stem from human capital theory (Becker, 1962). The approach argues that every extra year of education results in an increase in knowledge and skills, which lead to higher productivity and, therefore, higher wages. The empirical literature confirms this assumed relationship between wages and years of schooling. For Switzerland, a number of studies show that each additional year of schooling/education is associated with 
an increase in wages (Cattaneo \& Wolter, 2018; Tuor \& Backes-Gellner, 2010; Weber \& Wolter, 1999; Wolter \& Weber, 2005).

However, the human capital theory falls short in explaining wage differences between people with similar years of education but different occupation-specific skills. The reason is that the relative value of skills and thus their returns depend on their demand by employers (Autor et al., 2003). In order to conceptualise employers' demand and formulate assumptions regarding its impact on individual returns, we make use of the task-based approach by Autor et al. (2003). It argues that the demand for some working tasks has decreased within the last decades due to computerisation and automation. As a result, jobs with large shares of these tasks offer lower wages (Goos, Manning, \& Salomons, 2010; Liu \& Grusky, 2013; Oesch, 2013; Rohrbach-Schmid \& Tiemann, 2013).

\subsection{Determinants of Long-Term Returns to Professional Education}

From a supply-side perspective and based on human capital theory, an increasing level of education increases the level of individual productivity, which is remunerated by employers (Becker, 1962). Becker argues that the productivity of a person is a function of investment in knowledge and skills, which determine the expected lifetime income. An investment in human capital is profitable as long as the costs of every further unit of education or training do not exceed their expected utility (Becker, 2011). Consequently, workers' productivity and thus their earnings should increase continuously after completion of formal education, because workers accumulate experience throughout their working life. This increase in both productivity and wages should be observable in the early and middle career but may diminish thereafter because skills depreciate over time (Mincer, 1974). Based on human capital theory, and taking into account that professional education teaches competencies for demanding technical or management positions (SBFI, 2018), we therefore assume that professional education increases the average wage of workers over time compared to their average wage before graduation and that these returns become constant or even decrease in the later career.

\subsection{Determinants of Occupation-Specific Returns}

From a demand perspective, two aspects are important. Firstly, the demand for skills has undergone profound changes within the last decades (Autor et al., 2003; Firpo, Fortin \& Lemieux, 2011; Liu \& Grusky, 2013). Secondly, professional education is occupation-specific. Consequently, the demand for skills is likely to differ between occupations and affects the returns to education. In order to conceptualise potential differences between occupation-specific types of professional education, we make use of the task-based approach of Autor et al.
(2003), also called the "skill-biased technological change" approach (SBTC). It connects job tasks with skills by classifying jobs regarding their core task and identifying the skills necessary to carry out these activities. With regard to work tasks, the SBTC approach distinguishes between two main dimensions: routine/non-routine tasks and manual/non-manual tasks. The combination of these dimensions results in four different tasks: routine cognitive tasks, routine manual tasks, non-routine manual tasks, and non-routine non-manual tasks. The latter task type is often further divided into non-routine analytical and interactive tasks (Spitz-Oener, 2006; Williams \& Bol, 2018).

Autor et al. (2003) assume that routine tasks require fewer skills than non-routine tasks. Whereas routine tasks require little analytical effort, non-routine tasks are more heterogeneous and variable and require more cognitive effort and abilities. Furthermore, routine tasks can, compared to non-routine tasks, be fully specified as a series of instructions to be executed by a machine. Manual tasks represent physical tasks and require a lot of physical effort. Routine cognitive tasks represent general cognitive occupational skill requirements, such as calculating, correcting texts/data, or measuring tasks, which require less (and more repetitive) cognitive effort than nonroutine tasks. Analytical tasks require problem-solving, evaluating and planning skills, or skills for working out and interpreting rules. Interactive tasks subsume, for example, negotiating, teaching, entertaining, caring, or presenting skills (Spitz-Oener, 2006).

The task-based approach argues that due to technological and economic change within the last decades, namely computerisation and a shift from a production to a service economy, the demand for the five types of tasks has profoundly changed. Routine tasks-and in particular manual routine tasks-have decreased, although they have not disappeared altogether. Non-routine tasks and high-skilled work have risen in importance (Acemoglu \& Autor, 2011; Autor et al., 2003; Buera \& Kaboski, 2012; Drucker, 1954). This has led to an increasing demand for highly skilled workers who are able to complete non-routine work tasks (Autor et al., 2003). Their ensuing higher bargaining power results in higher wages (Pissarides, 2000).

More precisely, the literature shows that the growth of the service sector, as well as technological change, has led to an increase in the demand for non-manual tasks. The demand for manual skills has decreased, and they are mainly sought after in medium- and low-wage occupations (Autor \& Handel, 2013; Firpo et al., 2011). Furthermore, and due to automation, routine cognitive and routine manual tasks have been replaced by computers. This has led to a decrease in their relative market value (Autor et al., 2003; Spitz-Oener, 2006).

The shifts in the demand for (non-)routine and (non-)manual tasks over the last decades have been observed in most Western countries (Autor et al., 2003; Jerbashian, in press). This also holds for Switzerland, where the picture is similar. The service sector has 
grown in size whereas agriculture and production have shrunk (Sheldon, 2005). Furthermore, the demand for high-skilled workers-particularly for workers with tertiary-level education-has risen, while the demand for unskilled work has decreased (Sacchi, Salvisberg, \& Buchmann, 2005). This process was accompanied by an expansion of the tertiary education system in Switzerland (Buchmann, Sacchi, Lamprecht, \& Stamm, 2007). Regarding work tasks, Oesch and Rodriguez Menes (2011) and Aepli et al. (2017) confirm that the importance of analytical and interactive non-routine tasks has risen, whereas manual routine tasks have decreased (Aepli et al., 2017; Oesch \& Rodriguez, 2011). In addition, and rather surprisingly, Aepli et al. (2017) also find a slight increase in manual non-routine tasks since 1990.

The distinction between the five task types is idealtypical. Fernández-Macías and Hurley (2016) show, for example, that the significance of routine tasks may differ by work context. Whereas the dominant concept of routine tasks refers to tasks characterised by the methodical repetition of a procedure, which correlates negatively with cognitive effort, routine tasks may also serve to optimise performance, as is the case with musicians, for example. In the latter case, routine tasks are associated with high cognitive requirements. However, despite this element of blurring between the categories, the SBTC task concept has been useful in previous studies in order to explain differences in wage returns.

For the US, the results showed that wages of (high) skilled workers have increased more over time since the 1970s compared to wages of low skilled workers (Acemoglu \& Autor, 2011). Furthermore, analytical skills, such as problem-solving, managing, or supervising, have correlated with higher wages in recent times compared to the 1980s (Autor \& Handel, 2013; Liu \& Grusky, 2013). For Germany, Spitz-Oener (2006) and Dustmann, Ludsteck and Schoenberg (2009) find a similar, albeit slightly postponed development. Their results show that wages of high skilled workers have increased more significantly compared to the wages of low skilled workers. The available evidence for Switzerland is in line with these findings. Between the years 1990 and 2008, employment and earnings increased most at the top of the occupational structure (Oesch \& Rodriguez, 2011). Furthermore, Aepli et al. (2017) observed the highest wage increases within the last decade for analytical and interactive nonroutine tasks.

In summary, these findings imply that changes in the demand for certain tasks are related to changes in their market price. Consequently, we expect that these changes in task demand, which have been on-going for several decades, affect the returns to education in general and to professional education in particular. Although professional education should generally lead to a larger share of non-routine tasks, the extent of this change is likely to differ considerably between occupational fields. Whereas in some fields, routine manual and/or cognitive tasks may almost disappear for workers with pro- fessional education, these tasks may remain sizeable in others.

Based on the SBTC approach, our basic assumption is that the returns to professional education are related to the task changes induced by professional education. Firstly, we assume that the increasing demand for analytical and interactive non-routine tasks should lead to a higher monetary value of these tasks. Therefore, we posit that returns to professional education will be higher in occupational fields where professional education leads to jobs characterised by a strong increase in interactive and analytical tasks compared to the jobs of workers with IVET only.

Secondly, with regard to manual non-routine tasks, two opposing trends may be at work. On the one hand, the demand for manual tasks has decreased or stagnated due to the shrinking industrial sector. This is likely to have had a detrimental effect on returns. On the other hand, non-routine tasks are difficult to automate and may not be replaced. This may have had a positive effect on wages. If the first tendency prevails, we would expect limited returns to professional education in occupational fields where professional education leads to an increase in manual non-routine tasks. Based on the second tendency, we would expect to find increasing returns due to professional education in occupational fields where professional education leads to jobs with higher shares of manual non-routine tasks.

Thirdly, the prediction regarding cognitive routine tasks is also not entirely straightforward. Based on the classical SBTC assumption that the demand for, and consequently the monetary value of, cognitive routine tasks has been decreasing due to automation, we would expect that professional education which leads to jobs with an increasing share of manual routine tasks correlates with low returns. However, as described above, the demand for manual non-routine tasks is still surprisingly high in the Swiss labour market. Whether it has been sufficiently high to positively affect returns to professional education is an empirical question. Fourthly, the decreasing demand for routine manual tasks due to computerisation should have led to a lower monetary value of routine manual tasks. We expect lower returns in occupational fields where a professional education program leads to an increasing share of manual routine tasks.

Finally, average occupation-specific wages may be related to the coverage of collective agreements, i.e., binding industry-or occupation-specific conventions for minimum wages of workers with certain skills. Collective agreements result from successful wage negotiations between employee associations, such as labour unions and employer associations. In Switzerland, collective wage agreements, also called "GAV", cover about $40 \%$ to $50 \%$ of all employees during our observation time (BFS, 2018; Lampart \& Kopp, 2013; Oesch, 2011).

The findings regarding the relationship between wages and collective agreements are inconsistent. For the US, Canada, and the UK, Card, Lemieux and Riddell 
(2004) find, for example, that collective wage agreements negotiated by unions tend to reduce wage inequality between workers. However, the results also show that the higher wages in industries with union coverage are due to the higher skill level of the respective workers. For Switzerland, Visser and Checchi (2009) find no significant correlation between union coverage and returns to education. However, union coverage and collective wage agreements are not fully congruent. Consequently, it remains an open question of whether collective wage agreements affect returns to professional education in Switzerland. ${ }^{1}$

\section{Data and Methods}

\subsection{Data and Sample}

We use the Swiss Labour Force Survey (SLFS) of the Federal Statistical Office from 1991-2016. The Dataset is designed as a rotating panel and provides information on the structure of the labour force and employment patterns in Switzerland. The SLFS is based on a random sample stratified by cantons. Until 2009, respondents were interviewed once a year for a maximum of 5 consecutive years. From 2010 onwards, interviewees remained in the sample for a maximum of 2 years (BFS, 2017). We limit our sample to individuals born between 1951 and 1971 who hold a vocational education diploma and are aged between 20 and 65 in the observed years from 1991 to 2016. We thus use the regular retirement age for men as an upper limit. The lower limit is set at 20 years as the youngest possible age to enter professional education (BFS, 2007). This basic sample of 69543 individuals thus covers the complete working life. 10189 individuals of this sample have also earned a professional education certificate. In order to estimate the average returns to professional education by occupational group, we select a subsample of individuals for whom we have information on income before and/or after completion of professional education. Including the control group without professional education, this sample includes 28565 individuals, which we observe between two and five consecutive years.

\subsection{Methods}

\subsubsection{Estimation Strategy}

The estimation of long-term returns to education poses two problems: longitudinal data covering a long time- span are needed, and self-selection into higher education due to unobserved characteristics ("unobserved heterogeneity") has to be controlled. The available data for Switzerland-including the SLFS-do not provide sufficiently large samples or observation spans. Furthermore, the available data do not include information on ability or motivation, and estimation results could, therefore, be biased. Deaton (1985) proposes a solution to both problems. In order to optimise the estimation of average population values, he suggests creating a "quasi-panel" by grouping individuals of cross sections by fixed characteristics. Deaton demonstrates that with a high number of observations per created cohort and cross-section, the sample cohort and population cohort means at each point in time are comparable. This method allows for the estimation of cohort fixed effects as well, because demeaning of the variables over time and cohort becomes possible. The creation of such a quasi-panel allows for the use of cross-sectional or short panel data to investigate long-term developments with data "repeatedly collected from random samples drawn from the same time-stable cohort of individuals rather than repeatedly from the same specific individuals" (Russell \& Fraas, 2005, p. 2). The problem of unobserved heterogeneity is tackled by the use of a fixed effects estimator isolating the so-called "within variation". To create a quasi-panel, we first define a treatment and a control group. While the latter includes all individuals holding a VET diploma only and are therefore eligible to enter professional education, the treatment group includes all individuals who first completed upper-secondary vocational education and training and earned a professional education diploma later. The average treatment effect (of the treated) is the average individual wage difference before and after professional education, based on all individuals of the treatment group.

Second, we sort and aggregate the individuals of the treatment group by their year of graduation from professional education between 1991 and 2014. ${ }^{2}$ After data cleaning, this procedure yields a sample of 22 graduation cohorts and one control group, which we observe over a maximum of 25 years. ${ }^{3}$ Because our sample size differs within cohorts over time, the precision of the cell means differs. Following Russell and Fraas (2005), we correct our results for possible heteroscedasticity by using cell sizes as weights. ${ }^{4}$ To sum up, the creation of a quasi-panel allows us to investigate the long-term returns to professional education by estimating the "average treatment effect of the treated (ATET)", which is the average difference of individuals in the treatment group before and af-

\footnotetext{
${ }^{1}$ Due to lacking data, we are not able to answer this question in the present study.

2 Since exact exam dates are unknown, we count the exam-year as a pre-treatment time point.

3 Some individuals of the control group may enter professional education at an unobserved later date. These potential "high achievers" could bias our estimates by increasing the observed average yearly gross income of the control group without professional education. In order to control for this potential bias, individuals remain in the control group without professional education until the year in which they earn their degree.

${ }^{4}$ After controlling for autocorrelation with the stata procedure "xtserial" we find some weak indication for autocorrelation (Brüderl \& Ludwig, 2015; Cameron \& Miller, 2015). We also test for heteroscedasticity by including cluster-robust standard errors. We find the expected upward changes in the values of standard errors. However, because the differences are minimal and do not change the p-values of any of our estimates, we do not apply standard error correction.
} 
ter the treatment (Brüderl \& Ludwig, 2015). In our case, the average treatment effect is implemented as a "distributed fixed effect", measuring the development of the returns to professional education more precisely than the usual dichotomous fixed effects estimator, because it compares the average of all time points before with each point in time after the treatment (Dougherty, 2005).

In order to explore differences in the income development between occupational groups, we would ideally use the described quasi-panel design and estimate the effects by occupation using a fixed effects estimator. However, the large number of cases needed per cohort and year (see Verbeek \& Nijman, 1992) is not available. Alternatively, we use our sample on the individual data level and follow a three-step procedure. First, we estimate the average short-term returns to professional education by occupational group (3-digit SBN 2000 level) using a fixed effects estimator at the individual level. Second, we aggregate the data by occupational group. This procedure yields average values for 39 groups of occupations. Third, we use an OLS regression to explain the relationship between tasks and average return differences to professional education between 39 occupational fields (model II). Again, using a fixed effects estimation strategy allows us to wipe out the "contaminated" betweenvariation (Allison, 2009, p. 3). ${ }^{5}$

\subsubsection{Variables}

Our estimation of the returns to professional education (model I) is based on the cohort average of the natural logarithm of individual gross yearly income. We calculate full-time equivalents based on 42 weekly working hours. The income data are adjusted for inflation. ${ }^{6}$ We measure the long-term returns to professional education by using a variable which compares the average income before professional education with each time point after completing professional education. This so-called distributed fixed effect captures the wage development over time. Furthermore, we control the average age within each graduation cohort at each point in time (age effect) and include a categorical time variable (period effect) into model I. The latter measures the average wage development over time and controls the economic cycle. Finally, the variable ratio of the labour market demand for IVET and professional education diploma holders captures the yearly occupation-specific ratio of labour demand for IVET and professional education diploma holders. The indicator is measured at the two-digit level of the
Swiss standard classification of occupations (SBN2000, 39 occupational fields) and based on Swiss Job Monitor data (Sacchi, 2014). It captures the annual occupation-specific job openings for workers with an IVET diploma or with a professional education degree, weighted by the access probability of the opening with a given credential (for details see Kriesi, Buchmann, \& Sacchi, 2010; Sacchi, Kriesi, \& Buchmann, 2016). Representative data of the advertised open positions in Switzerland, the Swiss Job Monitor Data (Sacchi, 2014), were used to measure the demand side. The calculation of the mobility weights, capturing the degree to which open positions in one occupation are accessible for individuals with another occupational background, is based on the Swiss Census 2010. The index thus represents individual occupation-specific job opportunities at the time of entering employment in the current workplace. Higher numbers on the index are associated with better opportunities for IVET diploma holders.

The dependent variable of our second model (model II), which estimates the average occupation-specific determinants of returns to professional education, is the average yearly income difference before and after professional education for 39 occupational groups, measured at the 3-digit level of the SBN 2000 (see Table A1 in the Appendix). The construction of this variable is based on 39 auxiliary fixed effects regressions with the inflationadjusted logarithmic yearly gross income as a dependent variable, a dummy measuring the mentioned income change and a time variable capturing the survey wave. The results of the auxiliary regression for the occupational group specific returns are shown in Figure 1.

Regarding the task operationalisation, we make use of Spitz-Oener's (2006) categorisation, which distinguishes between (1) cognitive routine tasks, (2) manual routine tasks, (3) analytic tasks, (4) interactive tasks, and (5) manual non-routine tasks. We calculate five indicators, which measure the difference in the work tasks before and after completing professional education. The indicators capture the average difference in the share of task $X$ in occupation $Y$ between workers holding IVET and professional education diplomas. The measures are based on the German BIBB/BAUA Employer Survey (Hall, Siefer, \& Tiemann, 2018; Hall \& Tiemann, 2009; Jansen \& Dostal, 2015). In order to cover all of our observation years, we used the waves of 1999, 2006, and 2012. We make use of German data because no Swiss task data is available. However, due to the strong similarity of the German and Swiss occupational systems, we consider this approach feasible. ${ }^{7}$

\footnotetext{
${ }_{5}^{5}$ Tests for temporal homogeneity (Brüderl \& Ludwig, 2015) and Hausman tests (Hausman, 1978) confirm that fixed effects models are an appropriate strategy of analysis due to a correlation between our explanatory variables and the unobserved person- or group-specific characteristics (the so-called "person or cohort-specific error terms").

${ }^{6}$ For individuals with several wage observations before the transition to professional education, we calculate the average across the observed years. Based on a Kruskal-Wallis rank sum test we find no statistically significant differences in the average income of respondents with 1,2,3 or 4 observations before completing professional education (Chi-Square value of 2.179; $p=0.5362$ ). Respondents are nearly equally distributed over the 4 different points in time. Furthermore, men and women still follow different working time regimes in Switzerland. Because men in our data work full-time about twice as often as women, we use full-time equivalents.

${ }^{7}$ In order to test the validity of using German data, we systematically compared the task description of some training occupations based on the information issued by SERI (2019) and IAB/Berufenet (2019). Using carpenters as an example, the results show that the described tasks of this training occupation are almost identical in Germany and Switzerland (see Appendix, Table A4).
} 


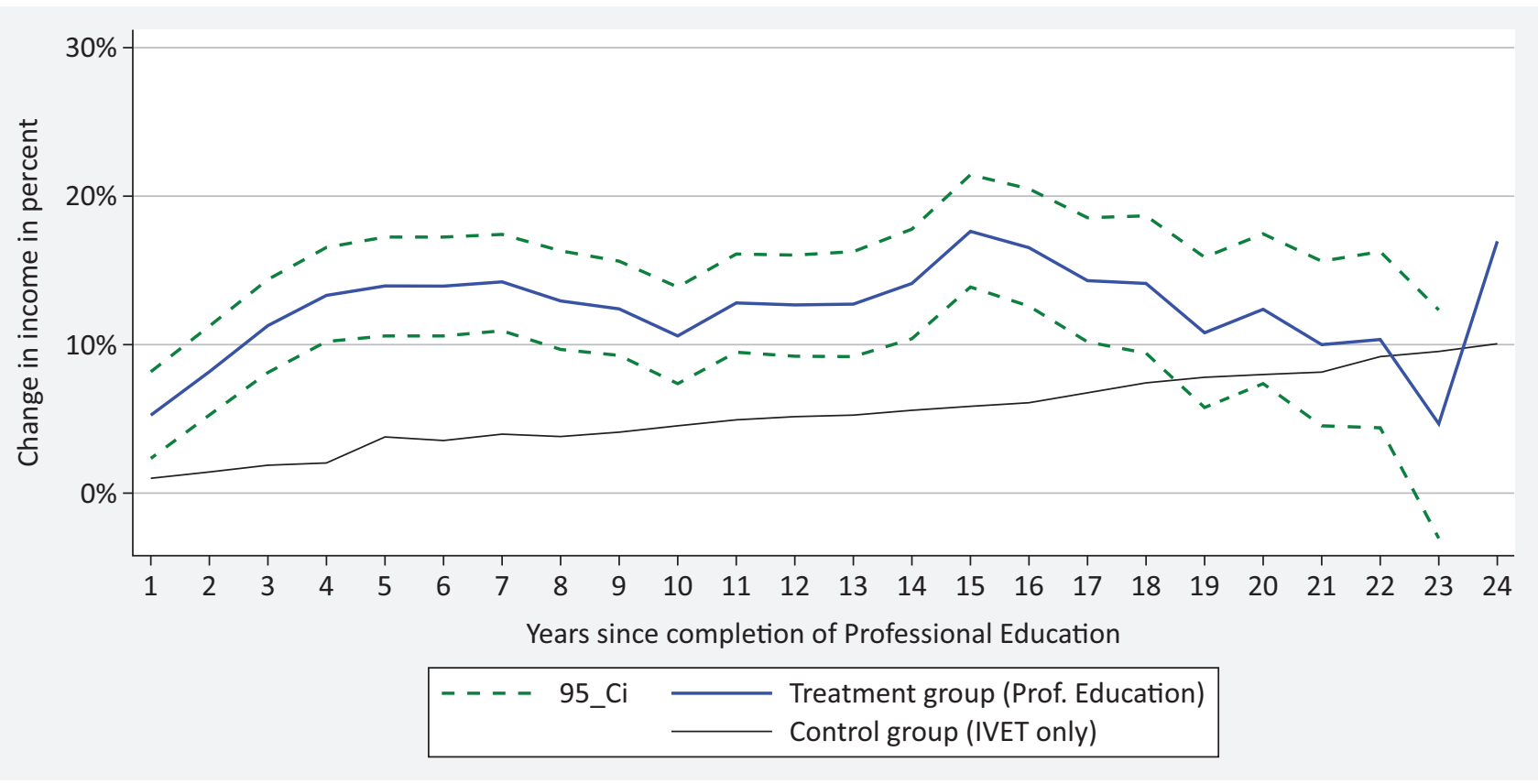

Figure 1. Income change due to professional education (impact function).

Regarding our control variables, we estimate the ratio of professional education graduates to IVET diploma holders per occupational field based on the SLFS data. The reason is that the transition probability into professional education may be influenced by the average returns within an occupational field, leading to a selection bias. In other words, the probability to complete professional education may be higher in occupational fields offering higher returns for professional education diploma holders compared to fields with lower returns. We also include workers' wages before completing their professional education, averaged by occupational group, in order to control for disproportional wage increases between occupational fields. Furthermore, we include the average age of workers because we assume lower returns with increasing age ${ }^{8}$ and the occupation-specific change in the share of female workers. The reason is that female-dominated occupations often go along with lower returns. Possible reasons are a devaluation of female-typed tasks or lower investment of women in well-paid specific human capital (Becker, 1971; Leuze \& Strauß, 2016). Finally, we control for company size. Large companies have more financial resources, which might lead to higher returns in large companies (Oi \& Idson, 1999). Tables 1 and 2 provide an overview of all variables. ${ }^{9}$

\section{Results}

We will begin by presenting our results for the average long-term returns of professional education. In the second section, we describe the differences between oc- cupational fields regarding wages and changes in task shares before discussing the relationship between tasks and returns in the third section.

\subsection{Long-term Returns to Professional Education}

Our results regarding the long-term returns to professional education are shown in Table A2 in the Appendix and illustrated in Figures 1 and 2. The coefficients for the years in Table A2 show the distributed fixed effects up to 24 years after graduation. They represent the annual wage increase after completing professional education compared to the average wage before graduation. Figure 1 shows that, although the trend of the impact variable is not entirely linear-partly due to a varying number of observations per year-the general trend is clear-cut. It shows increasing returns to professional education over time from on average $7 \%$ right after graduation to almost $18 \%$ in the 15 th year after earning the degree. Afterward, returns diminish slightly over time and even out about 20 years after graduation at an average value of approximately $10 \%$. This downward trend may partly be due to a low number of observations for the last years and should be regarded with caution. The development of the control group with IVET also only shows an upward trend but on a considerably lower level.

In order to calculate the average wage increase across the entire observation span, we estimated a model with a dummy variable instead of the distributed fixed effects variable. It captures the average wage change across all graduation cohorts (see Table A3 in the Appendix). It reveals the average long-term returns

\footnotetext{
${ }^{8}$ No differences in the age effect were found using a median age.

${ }^{9}$ Due to a lack of data, we do not control for union coverage.
} 
Table 1. Descriptive overview of variables for model I.

\begin{tabular}{|c|c|c|c|c|}
\hline Variable & Mean & Std. Dev. & Min & Max \\
\hline Overall average gross yearly income & 99943.96 & 11701.09 & 64111.44 & 129976.1 \\
\hline Logarithm of overall average gross yearly income & 11.45 & .11 & 11.04 & 11.67 \\
\hline Distributed fixed effect (number of years after graduation) & 7.37 & 6.15 & 0 & 24 \\
\hline Average age per cohort and year & 43.11. & 5.98. & 29 & 53 \\
\hline Ratio labour demand for professional education/IVET & 16 & 6.82 & 2 & 44 \\
\hline Year & 2006 & 6.07 & 1991 & 2015 \\
\hline N_total (Total sample size) & 69543 & & & \\
\hline $\mathrm{N}$ total_cohort (Cohort sample size (quasi-panel)) & 443 & 1400 & 3 & 8172 \\
\hline Number of cohorts & 23 & & & \\
\hline
\end{tabular}

Table 2. Descriptive overview of variables for model II.

\begin{tabular}{|c|c|c|c|c|}
\hline Variable & Mean & Std. Dev. & Min & Max \\
\hline Average short term returns to professional education (\%) & 3.77 & 8.13 & 23 & 23 \\
\hline \multicolumn{5}{|c|}{ Average relative task change between workers with professional education and iVET : } \\
\hline Relative change of analytic non-routine tasks & 9.64 & 20.85 & -55 & 50 \\
\hline Relative change of interactive non-routine tasks & 14.79 & 27.65 & -62 & 93 \\
\hline Relative change of manual non-routine tasks & -3.79 & 31.95 & -47 & 125 \\
\hline Relative change of cognitive routine tasks & -.872 & 10.49 & -26 & 26 \\
\hline Relative change of manual routine tasks & -2.13 & 25.72 & -37 & 75 \\
\hline Average wage before professional education (in $1000 \mathrm{CHF}$ ) & 80.87 & 14.95 & 58 & 127 \\
\hline Average age & 38.79 & 4.98 & 30 & 51 \\
\hline Change of share of women (\%) & 25.23 & 34.56 & 0 & 100 \\
\hline \multicolumn{5}{|l|}{ Average company size ( $r e f=$ medium and large companies) } \\
\hline Small & .51 & .50 & 0 & 1 \\
\hline Medium \& large & .10 & .31 & 0 & 1 \\
\hline Ratio of professional education graduates (\%) & 3.41 & 2.75 & 0 & 13 \\
\hline Sample size (No occupational fields) & 39 & & & \\
\hline
\end{tabular}

of approximately $11 \%$. Regarding the short-term returns, our results confirm Cattaneo's (2011) estimate of approximately $7 \%$ higher earnings right after completion of professional education. However, our long-term estimations based on the quasi-panel method refer, with an average of $11 \%$, to the first third of Cattaneo's long-term calculations, which range from $-4 \%$ to $29 \%$, depending on the cost scenario. Consequently, most of her cost scenarios are considerably higher than our estimates.

To test the robustness of our results, we re-estimated our model by a) reducing the observation span to 15 years after graduation, b) reducing the graduation cohorts to those observable for a maximum of 15 years (graduation cohorts from 2001 to 2014), and by c) reducing the graduation cohorts to those observable for the entire time-span of 24 years (graduation cohort of 1991-2000). All estimates result in similar average return values between $10 \%$ and $12 \%$ (see Table A3 in the Appendix). We therefore conclude that our estimates of the long-term returns are robust and not affected by the observed downward trend in returns approximately 15 years after graduation.

The year dummies in our model control for time trends (period effects). They include the wage development of the control group with IVET only and of work- ers with professional education. The development is illustrated in Figure 2. Compared to the reference year of 1991, almost all coefficients show positive values. This indicates a general upward trend in wages for IVET and professional education certificate holders. The average age of the respondents has no significant effect on wage development. Consequently, the wage increase over the career is not related to the average cohort age at graduation. Finally, the variable measuring the ratio of the demand for workers with professional education and workers with initial VET is positive and statistically significant. This implies that the returns to professional education increase if the demand for workers with professional education is higher than the demand for workers with initial VET only. If the ratio increases by $10 \%$, the average wages for people with professional education increase by $5 \%$.

\subsection{Wage Differences between Occupational Fields}

In order to examine wage differences between occupational fields, we have run auxiliary regressions, which estimate the average short-term returns for 39 occupational fields. The results are illustrated in Figure 3. They show that the returns to professional education-albeit 


\section{COGITATIO}

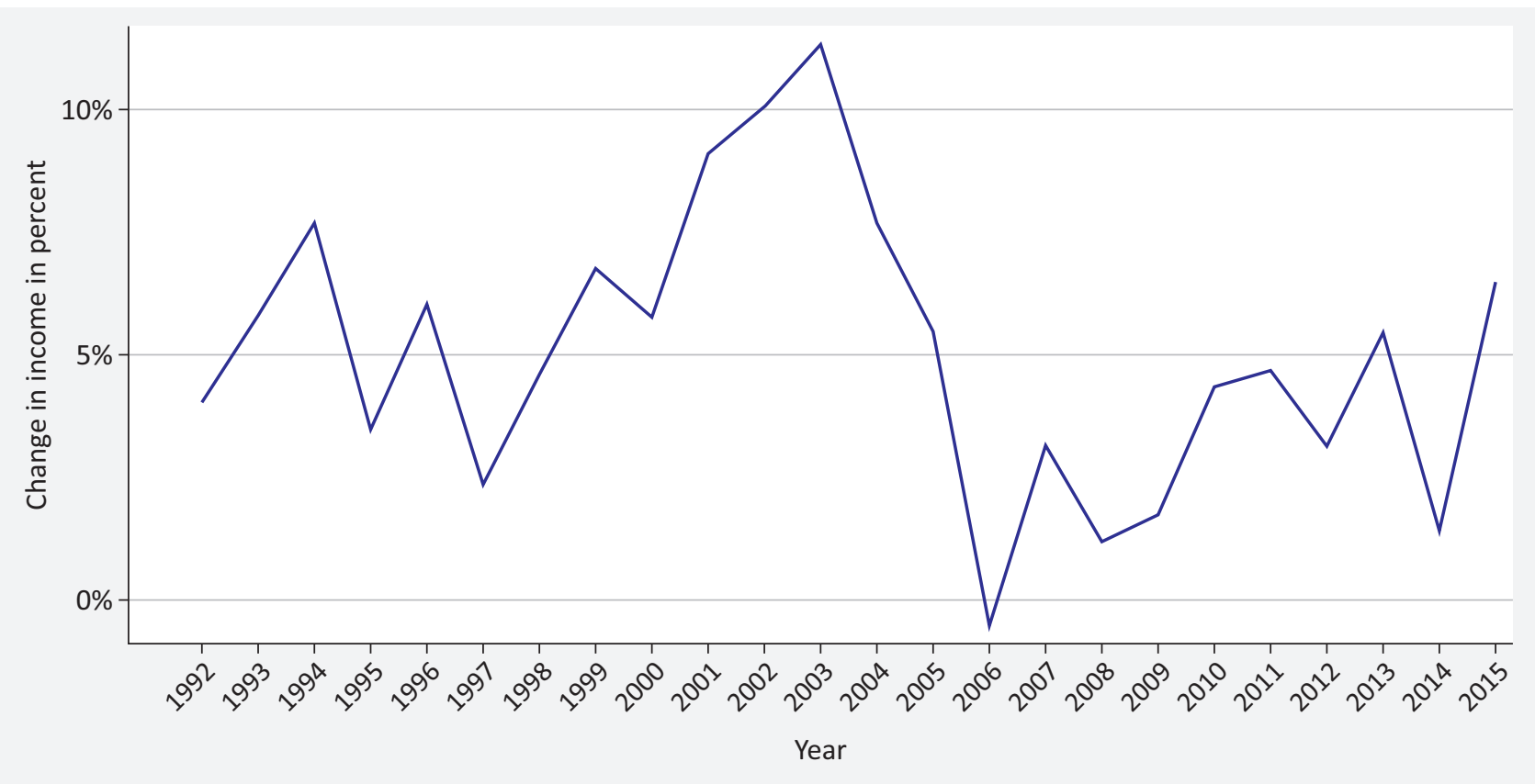

Figure 2. Average relative wage development of professional education and IVET only certificate holders (compared to the year 1991).

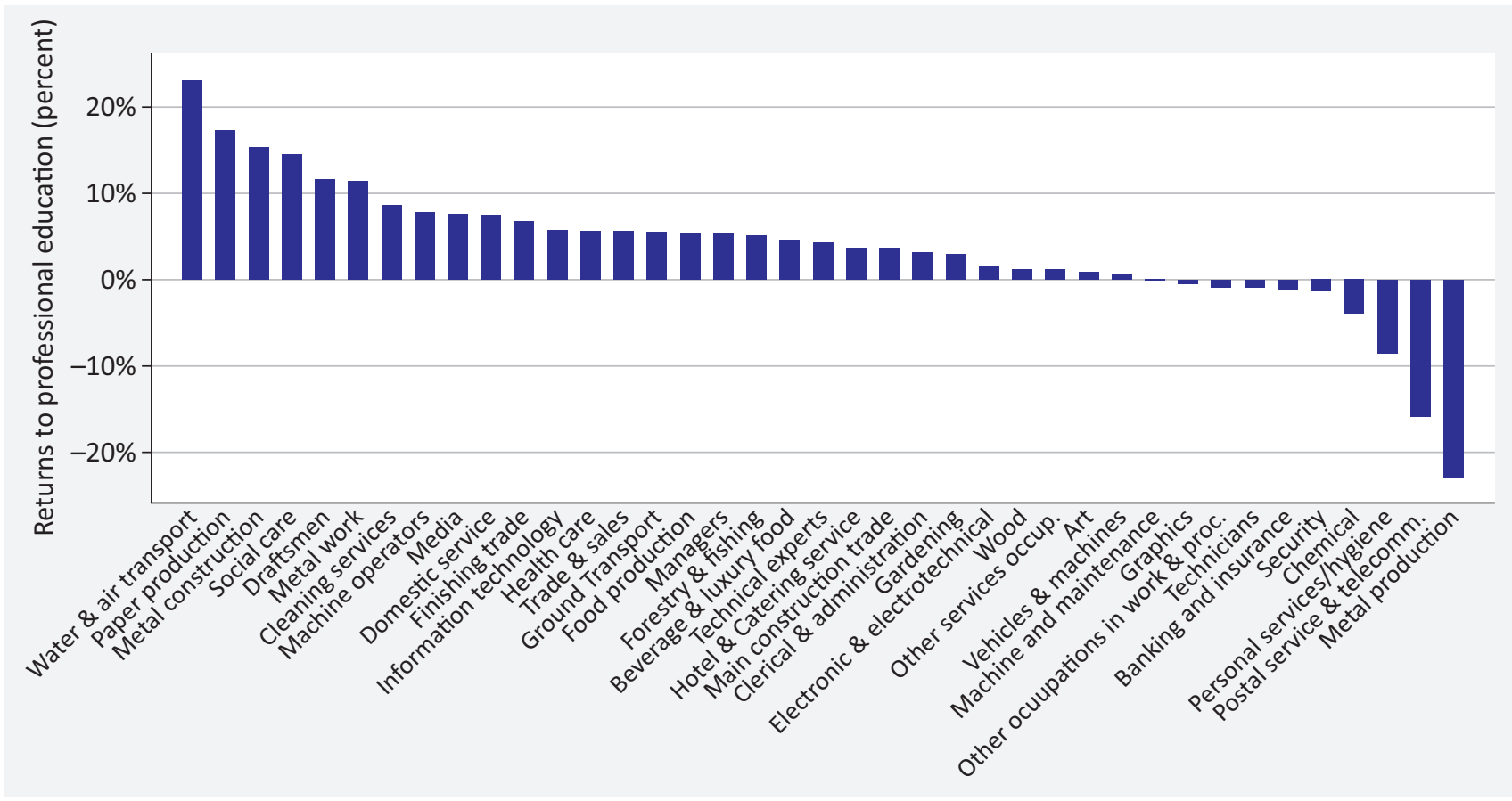

Figure 3. Mean return (\%) to professional education by occupational field.

mostly positive-do indeed vary considerably between the occupational fields. They range from average values of $23 \%$ in occupational fields like water $\&$ air transport or paper production to negative values of $-23 \%$ for metal production or personal service/hygiene.

Figure 4 illustrates the average relative task difference between workers with an IVET and a professional education diploma within an occupational field. In most occupational fields, completing professional education leads to an increase in analytic and interactive nonroutine tasks. The differences regarding cognitive routine tasks are small in most occupational fields. With a few notable exceptions, professional education is associated with lower shares of routine and non-routine manual tasks. Outliers regarding routine manual tasks are social care or personal services/hygiene. In these occupational fields, manual routine tasks are an integral part of skilled work. These findings thus support the assumption 


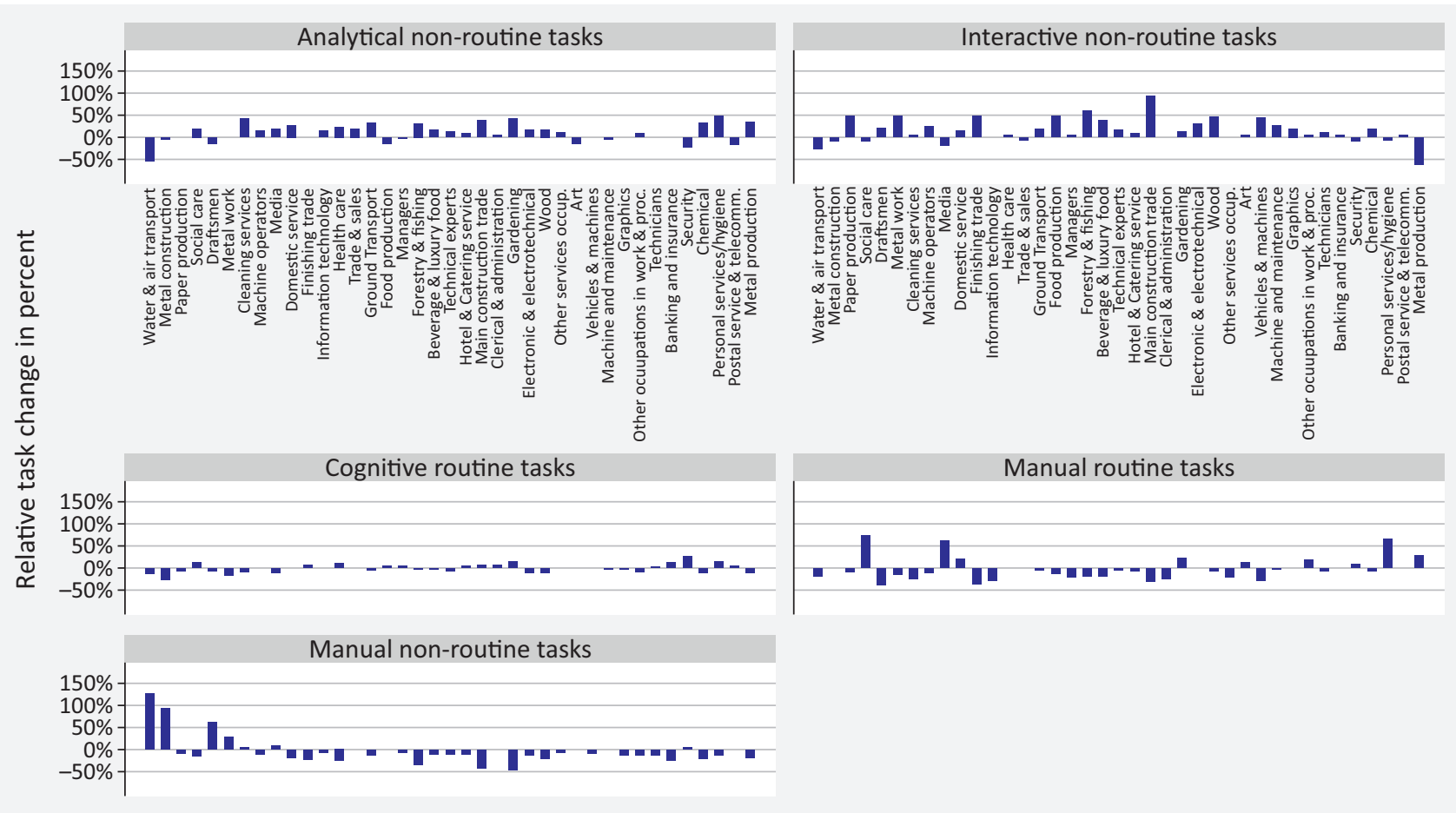

Figure 4. Relative change of task shares after professional education by occupational field, sorted from left to right by return size.

that some types of routine manual tasks go along with qualified work (see Fernández-Macías \& Hurley, 2016). Outliers for non-routine manual tasks are paper production or water and air occupations. In these fields, routine tasks dominate, and professional education leads to a shift from routine to manual non-routine tasks.
Figure 5 illustrates the bivariate correlation between the occupation-specific returns to professional education and the relative change of all three types of nonroutine tasks taken together. The pattern supports our hypothesis that an increase in non-routine tasks due to professional education goes along with higher returns.

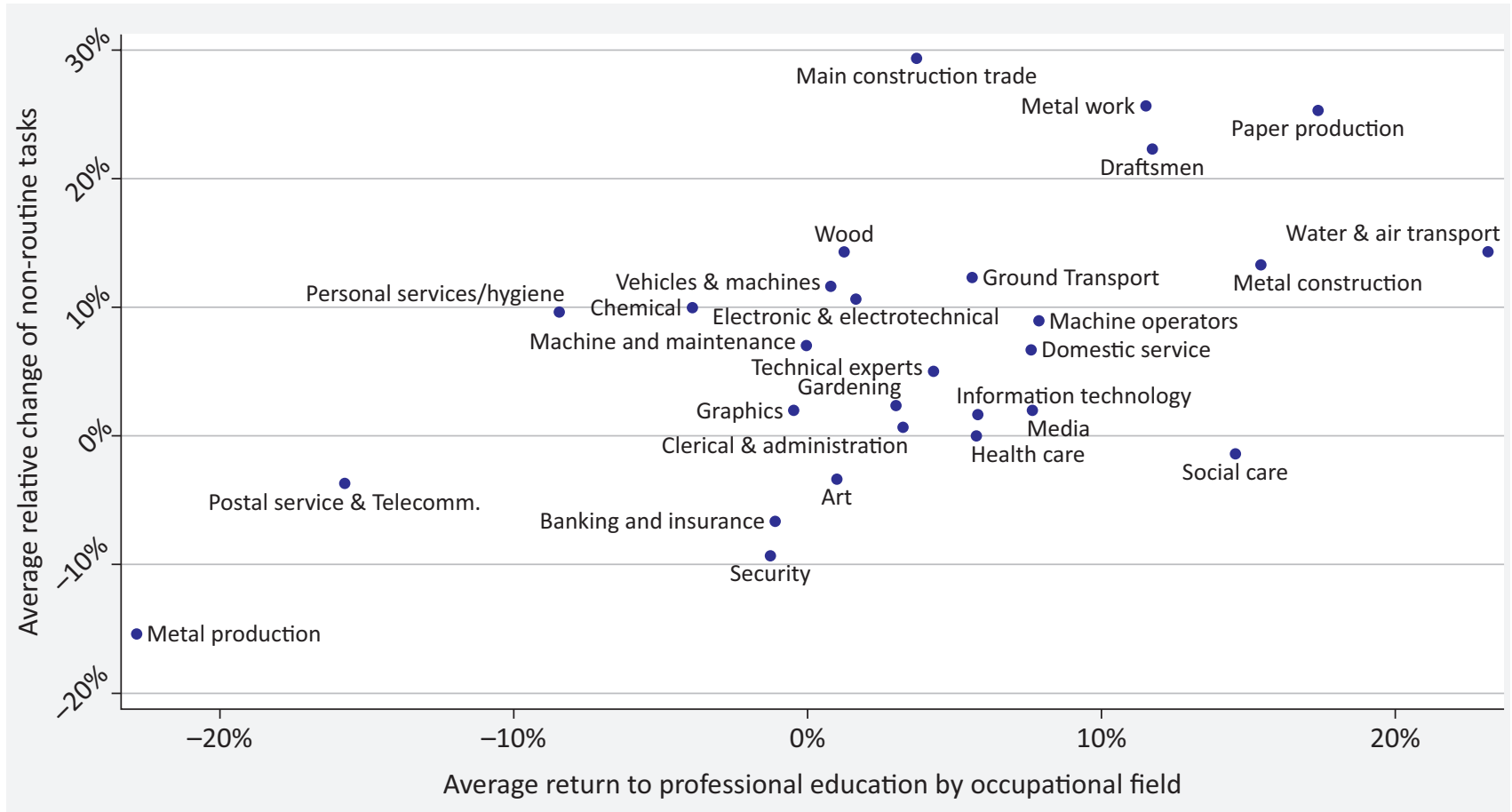

Figure 5. Correlation between the relative change of analytical and interactive non-routine tasks and returns to professional education by occupational field. 


\subsection{Determinants of Occupation-Specific Returns}

The relationship between a change in the share of work tasks and occupation-specific returns to professional education is illustrated in Table 3. As expected, we find a significant positive impact of analytical and interactive non-routine tasks. A $10 \%$ relative increase in the share of these two tasks goes along with higher average returns of around $2 \%$. Interestingly, manual non-routine tasks are associated with the strongest increase in returns. In occupational fields where professional education leads to a relative increase in manual non-routine tasks, returns increase strongest. A $10 \%$ relative increase in manual non-routine tasks leads to $3 \%$ higher returns. The comparatively high returns of manual non-routine tasks in Switzerland may, on the one hand, be due to the still fairly high prestige of craftsmanship. The prevalence and high quality of Swiss vocational education and training have helped to maintain the traditionally strong position of craft occupations. On the other hand, high returns may be explained by collective agreement coverage, which is higher in the secondary sector than in the tertiary sector in Switzerland (Lampart \& Kopp, 2013).

The relative change in the share of routine tasksmanual or cognitive-is not significantly related to returns to professional education. This is in line with the SBTC approach and may be explained with the diminishing importance and the decreasing demand for routine tasks in modern economies. The finding also shows that, although cognitive routine tasks are still prevalent in the Swiss labour market (Aepli et al., 2017), their monetary value is limited.

Regarding our control variables, neither the average wage before professional education nor average age nor the change of the share of women before and after professional education nor the company size nor the ratio of professional education graduates are significantly related to the occupation-specific returns to professional education.

\section{Discussion and Conclusions}

In Switzerland, initial VET diploma holders may continue their education at the tertiary level by earning a professional education degree. About one-third of all IVET diploma holders choose this option, usually after gaining some work experience (BFS, 2019). In order to investigate how much an investment in professional education pays in the long run in comparison with holding an IVET diploma only, we make use of a novel design which combines a quasi-panel cohort design with an experimental framework. The procedure yields short-term returns of approximately $7 \%$ and long-term returns of $11 \%$. The former figure is in line with results presented by Cattaneo (2011). However, her figures for long-term returns, which are based on projections of different cost scenarios, are in most cases higher than ours, and her highest value exceeds our results by as much as $18 \%$. This suggests that the long-term returns of professional education have hitherto been overestimated. Likely reasons are that changes in the demand for skills due to fluctuating business cycles or technological development cannot be taken into account with short-term data only. This disadvantage is greatly attenuated by our proposed method. It allows for a reliable simulation of longitudinal data with long observation spans which enable more precise and robust estimates of long-term returns.

In the second step, we analysed whether the returns differ between occupation-specific types of professional education and whether such differences are related to changes in the task composition associated with the transition from IVET to professional education. We found

Table 3. Model II-Results of (weighted) OLS regression.

\begin{tabular}{|c|c|c|}
\hline Returns to professional education & Coef. & Std. Err. \\
\hline Relative change of analytical non-routine tasks (in $10 \%$ ) & $1.85^{* *}$ & $(0.86)$ \\
\hline Relative change of interactive non-routine tasks (in 10\%) & $2.09 * * *$ & $(0.61)$ \\
\hline Relative change of manual non-routine tasks (in 10\%) & $2.94 * * *$ & $(0.62)$ \\
\hline Relative change of cognitive routine tasks (in $10 \%$ ) & 1.71 & $(1.45)$ \\
\hline Relative change of manual routine tasks (in 10\%) & 0.69 & $(0.56)$ \\
\hline Average wage before professional education (in $10000 \mathrm{CHF}$ ) & 0.10 & $(0.09)$ \\
\hline Average age & -0.28 & $(0.29)$ \\
\hline Change of share of women (in 10\%) & -0.66 & $(2.52)$ \\
\hline \multicolumn{3}{|l|}{ Average company size (ref = micro companies) } \\
\hline Small & 3.17 & $(2.77)$ \\
\hline Middle \& large & -4.46 & $(5.81)$ \\
\hline Ratio of professional education graduates & 0.58 & $(0.49)$ \\
\hline Constant & -0.38 & $(11.64)$ \\
\hline F-Test & $3.33^{* * *}(11,27)$ & \\
\hline Observations & 39 & \\
\hline Adj. R-squared & 0.40 & \\
\hline
\end{tabular}

Notes: Standard errors in parentheses; ${ }^{* * *} \mathrm{p}<0.01,{ }^{* *} \mathrm{p}<0.05,{ }^{*} \mathrm{p}<0.1$. 
that within most of the occupational fields, professional education has positive wage effects. However, the magnitude of the wage gains varies considerably due to varying occupation-specific differences in the task composition of IVET and professional education diploma holders. Wage gains increase significantly in occupational fields where professional education leads to an increasing share of non-routine tasks. This is in line with our assumptions, based on the task-based approach, and can be explained by the growing importance of non-routine tasks in the labour market.

This being said, it is important to note that these findings pertain to short-term returns only. We were not able to estimate long-term differences between occupational fields due to insufficient sample sizes. A drawback of the proposed quasi-panel method is the requirement of a very large number of observations per cohort and time points. This severely limits subgroup comparisons, for example by occupation, age, or gender. Furthermore, the available data sets for Switzerland lack information on individual characteristics, such as ability, school leaving certificates, or social background, as well as on workplace characteristics, which are potentially relevant for individual returns to education.

Despite these limitations, our article makes some important contributions to the existing literature. Firstly, our study demonstrates that the use of a quasi-panel cohort design compensates the lack of individual lifecourse data, which frequently hampers reliable estimates of returns to education. It enables us to observe long-term developments even if individual-level longitudinal data is unavailable. Secondly, the chosen method based on an experimental design combined with a fixed effects estimator allows for causal estimations at a cohort level and for controlling unobserved heterogeneity. We consider this approach to be a useful alternative to the sole estimation of short-term returns or of long-term returns, which are potentially biased by selfselection or unobserved heterogeneity. The reliable longterm estimation of returns to professional education is particularly important for Switzerland, where a large part of the workforce enters vocational education and makes use of this type of education to optimise their income prospects. A third contribution is a confirmation that the returns to professional education are very heterogeneous and partly determined by the occupationspecific changes in the task composition after completion of professional education. Whereas professional education pays off well in some occupational fields, the financial benefits, compared to IVET, are very small in others. Within the Swiss system, where the accessible programs of professional education strongly depend on the IVET training program, this implies that the prospects for an individuals' lifetime earnings are partly determined at the early age of 15 , when young people enter IVET.

In sum, our article contributes to the hitherto scarce research on Swiss professional education. However, many questions remain unanswered. Further research should, for example, aim at comparing the long-term returns to professional education with those for university or university of applied sciences education. It would also be important to gain more insights into differences in long-term returns between men and women, who still follow different working time regimes in Switzerland. Whether and to what extent part-time work has an influence on the returns to professional education, to our knowledge, has never been investigated. Last but not least, it would be desirable if the relative significance of work tasks, individual characteristics, and firm characteristics for returns could be investigated further.

\section{Acknowledgments}

We thank the two anonymous reviewers for their helpful and constructive comments on an earlier version of the manuscript. We further thank Prof. Dr. Ben Jann at the University of Bern for his comments and suggestions regarding the chosen method of analysis.

\section{Conflict of Interests}

The authors declare no conflict of interests.

\section{References}

Acemoglu, D., \& Autor, D. (2011). Skills, tasks and technologies: Implications for employment and earnings. In O. Ashenfelter \& D. Card (Eds.), Handbook of labor economics (Vol. 4B, pp. 1043-1171). Amsterdam: Elsevier.

Aepli, M., Angst, V., Iten, R., Kaiser, H., Lüthi, I., \& Schweri, J. (2017). Die Entwicklung der Kompetenzanforderungen auf dem Arbeitsmarkt im Zuge der Digitalisierung [The development of competence requirements in the labor market in the course of digitization.] Arbeitsmarktpolitik, 47.

Allison, P. D. (2009). Fixed effects regression models. Thousand Oaks, CA: Sage.

Autor, D. H., \& Handel, M. J. (2013). Putting tasks to the test: Human capital, job tasks, and wages. Journal of Labor Economics, 31, 59-96.

Autor, D. H., Levy, F., \& Murnane, R. J. (2003). The skill content of recent technological change: An empirical exploration. The Quarterly Journal of Economics, 118, 1279-1333.

Baron, J. N., \& Bielby, W. T. (1980). Bringing the firms back in: Stratification, segmentation, and the organisation of work. American Sociological Review, 45, 737-765.

Bassanini, A., Booth, A., Brunello, G., De Paola, M., \& Leuven, E. (2007). Workplace training in Europe (IZA discussion paper no 1640). Bonn: IZA.

Baumeler, C., Kriesi, I., \& Barabasch, A. (2017). Berufsbildungskarrieren jenseits der Akademisierung. Impulse zur Profilierung der Aufstiegsfortbildung aus schweizerischer Perspektive [Vocational training ca- 
reer beyond academization. Impetus for profiling advancement training from a Swiss perspective]. BWP, 3, 32-36.

Becker, G. S. (1962). Investment in human capital: A theoretical analysis. The Journal of Political Economy, 70, 9-49.

Becker, G. S. (1971). The economics of discrimination. Chicago, IL: University of Chicago Press.

Becker, R. (2011). Lehrbuch der Bildungssoziologie [Textbook of educational sociology]. Wiesbaden: Springer.

BFS. (2007). Abschlüsse der höheren Berufsbildung: Eine statistische Bestandsaufnahme [Higher vocational qualifications: A statistical inventory]. Neuchatel: BFS-Bundesamt für Statistik.

BFS. (2017). Die Schweizerische Arbeitskräfteerhebung ab 2010. Konzepte-Methodische Grundlagen, Praktische Ausführung [Graduations of the higher Swiss Labor Force Survey from 2010. Concepts, methodological basics, practical execution]. Neuchatel: BFSBundesamt für Statistik.

BFS. (2018). Erhebung der Gesamtarbeitsverträge in der Schweiz 2016 [Collecting collective labor agreements in Switzerland 2016]. Neuchatel: BFS-Bundesamt für Statistik.

BFS. (2019). Die Ausbildungssituation der Kandidatinnen und Kandidaten der höheren Berufsbildung. Ergebnisse der Erhebung zur höheren Berufsbildung 2017 [The training situation of the candidates of higher vocational education. Results of the VET survey 2017]. Neuchatel: BFS-Bundesamt für Statistik.

Böckerman, P., Haapanen, M., \& Jepsen, C. (2018). Labormarket returns to higher vocational schooling (IZA discussion paper no 11734). Bonn: IZA.

Brüderl, J., \& Ludwig, V. (2015). Fixed-effects panel regression. In H. Best \& Ch. Wolf (Eds.), The Sage handbook of regression: Analysis and causal inference (pp. 327-357). Los Alamitos, CA: Sage.

Brunello, G., \& Rocco, L. (2015). The effects of vocational education on adult skills and wages: What can we learn from PIAAC? OECD Social, Employment and Migration Working Papers, 168. http://dx.doi.org/10. 1787/5jrxfmjvw9bt-en

Buchmann, M., Sacchi, S., Lamprecht, M., \& Stamm, H. (2007). Tertiary education expansion and social inequality in Switzerland. In Y. Shavit, R. Arum, \& A. Gamoran (Eds.), Stratification in higher education. A comparative study (pp. 321-348). Palo Alto, CA: Stanford University Press.

Buera, F., \& Kaboski, J. P. (2012). The rise of the service economy. American Economic Review, 102, 2540-2569.

Cameron, A. C., \& Miller, D. L. (2015). A practitioner's guide to cluster-robust inference. The Journal of $\mathrm{Hu}$ man Resources, 50, 317-372.

Card, D., Lemieux, T., \& Riddell, W. C. (2004). Unions and wage inequality. Journal of Labor Research, 25, 519-559.
Cattaneo, M. A. (2011). New estimation of private returns to higher professional education and training. Empirical Research in Vocational Education and Training, 3, 71-84.

Cattaneo, M. A., \& Wolter, S. C. (2011). Der individuelle Ertrag einer höheren Berufsbildung [The individual return of a higher vocational education]. Die Volkwirtschaft, 12, 63-66.

Cattaneo, M. A., \& Wolter, S. C. (2018). Ist Bildung eine rentable Investition? [Is education a profitable investment?]. Die Volkwirtschaft, 3, 42-44.

Celeste, K. C., \& Sanford, T. (2018). Way station or launching pad? Unpacking the returns to adult technical education. Journal of Public Economics, 165, 146-159.

Deaton, A. (1985). Panel data from time series of crosssections. Journal of Econometrics, 30, 109-126.

Dougherty, C. (2005). The marriage earnings premium as a distributed fixed effect. The Journal of Human Resources, 41(2), 433-443.

Drucker, P. F. (1954). The practice of management. New York, NY: Harper Press.

Dustmann, C., Ludsteck, J., \& Schoenberg, U. (2009). Revisiting the German wage structure. Quarterly Journal of Economics, 124(2), 843-881.

Fernández-Macías, E., \& Hurley, J. (2016). Routinebiased technical change and job polarisation in Europe. Socio-Economic Review, 15(3), 1-23.

Firpo, S., Fortin, N. M., \& Lemieux, T. (2011). Occupational tasks and changes in the wage structure (IZA discussion paper no 5542). Bonn: IZA.

Goldthorpe, J. H. (2000). Social class and the differentiation of employment contracts. In J. H. Goldthorpe (Ed.), Sociology: Numbers, narratives and the integration of research and theory (pp. 206-229). Oxford: Oxford University Press.

Goos, M., Manning, A., \& Salomons, A. (2010). Explaining job polarization in Europe: The roles of technology, globalization and institutions (CEP discussion paper no 1026). London: Centre for Economic Performance, LSE.

Hall, A., \& Tiemann, M. (2009). BIBB/BAuAEmployment survey 2006 [GESIS Data Archive]. ZA4820 Data file version 1.0.1. http://dx.doi.org/ 10.4232/1.11072

Hall, A., Siefer, A., \& Tiemann, M. (2018). BIBB/BAuAErwerbstätigenbefragung 2012-Arbeit und Beruf im Wandel. Erwerb und Verwertung beruflicher Qualifikationen [Employment Survey 2012: Work and occupation in transition. Acquisition and utilization of vocational qualifications]. Bonn: Bundesinstitut für Berufsbildung. http://dx.doi.org/10.7803/501.12. 1.1 .50

Hausman, J. A. (1978). Specification tests in econometrics. Econometrica, 46, 1251-1271.

$\mathrm{IAB} /$ Berufenet. (2019). Job description of a carpenter. Berufenet. Retrieved from https://berufenet. arbeitsagentur.de/berufenet/bkb/4460.pdf

Jansen, R., \& Dostal, W. (2015). Erwerb und Verwer- 
tung beruflicher Qualifikationen 1998/99 (Qualifikation und Berufsverlauf). [Acquisition and utilization of vocational qualifications 1998/99 (qualification and professional development); GESIS Data Archive]. ZA3379 Data file version 1.1.0. http://dx.doi.org/10. 4232/1.12247

Jepsen, C., Troske, K. R., \& Coomes, P. A. (2012). The labor-market returns to community college degrees, diplomas, and certificates (IZA discussion paper no 6902). Bonn: IZA.

Jerbashian, V. (in press). Automation and job polarization: On the decline of middling occupations in Europe. Oxford Bulletin of Economics and Statistics.

Kriesi, I., Buchmann, M., \& Sacchi, S. (2010). Variation in job opportunities for men and women in the Swiss labor market 1962-1989. Research in Social Stratification and Mobility, 28, 309-323.

Lampart, D., \& Kopp, D. (2013). GAV in der Schweiz: Probleme, Handlungsbedarf, Lösungen [CLA in Switzerland: Problems, need for action, solutions]. Swiss Federation, Dossier no 95. Retrieved from https://www.sgb.ch/themen/arbeit/loehne-undvertragspolitik/artikel/details/dossier-nr-95-gav-inder-schweiz-probleme-handlungsbedarf-loesungen

Lemieux, T. (2015). Occupations, fields of study and returns to education. Canadian Journal of Economics, 47, 1047-1077. Leuze, K., \& Strauß, S. (2016). Why do occupations dominated by women pay less? How 'female-typical' work tasks and working-time arrangements affect the gender wage gap among higher education graduates. Work, Employment and Society, 30, 802-820.

Liu, Y., \& Grusky, D. B. (2013). The payoff to skill in the third industrial revolution. American Journal of Sociology, 118, 1330-1374.

Mincer, J. (1974). Schooling, experience, and earnings. New York, NY: National Bureau of Economic Research.

Murphy, E., \& Oesch, D. (2016). The feminization of occupations and change in wages: A panel analysis of Britain, Germany, and Switzerland. Social Forces, 94, 1221-1255.

OECD. (2011). Education at a glance 2011: OECD indicators. OECD-ilibrary. http://dx.doi.org/10.1787/eag2011-en

Oesch, D. (2011). Swiss trade unions and industrial relations after 1990. A history of decline and renewal. In C. Trampusch \& A. Mach (Eds.), Switzerland in Europe. Continuity and change in the Swiss political economy (pp. 82-102). London: Routledge.

Oesch, D. (2013). Occupational change in Europe. How technology and education transform the job structure. Oxford: Oxford University Press.

Oesch, D., \& Rodriguez Menes, J. (2011). Upgrading or polarization? Occupational change in Britain, Germany, Spain and Switzerland, 1990-2008. Socio-Economic Review, 9(3), 1-29.

Oi, W. Y., \& Idson, T. L. (1999). Firm size and wages. In
O. C. Ashenfelter \& D. Card (Eds.), Handbook of labor economics (pp. 2165-2214). Amesterdam: Elsevier.

Oreopoulos, P. (1972). The economic returns to higher education in twenty-five countries. Higher Education, 1, 141-158.

Parent, D. (2000). Industry-specific capital and the wage profile: Evidence from the national longitudinal survey of youth and the panel study of income dynamics. Journal of Labor Economics, 18, 306-323.

Pissarides, C. A. (2000). Equilibrium unemployment theory. Cambridge, MA: MIT Press.

Rohrbach-Schmidt, D., \& Tiemann, M. (2013). Changes in workplace tasks in Germany: Evaluating skill and task measures. Journal of Labour Market Research, 46, 215-237.

Russell, J. E., \& Fraas, J. W. (2005). An application of panel regression to pseudo panel data. Multiple Linear Regression Viewpoints, 31, 1-15.

Sacchi, S. (2014). Lange Messreihen zur Entwicklung des Stellenangebotes der Schweizer Wirtschaft: Kombinierte Presse-Online-Index [Long series of measurements on job vacancies in the Swiss economy: Combined Press Online Index]. (SMM Working Paper). Zurich: University of Zurich.

Sacchi, S., Kriesi, I., \& Buchmann, M. (2016). Occupational mobility chains and the role of job opportunities for upward, lateral and downward mobility in Switzerland. Research in Social Stratification and Mobility, 44, 10-21.

Sacchi, S., Salvisberg, A., \& Buchmann, M. (2005). Long-term dynamics of skill demand in Switzerland, 1950-2000. In H. Kriesi, P. Farago, M. Kohli, \& M. Zarin-Nejadan (Eds.), Contemporary Switzerland; revisiting the special class (pp. 105-134). New York, NY: Palgrave Macmillan.

SBFI. (2018). Vocational and professional education and training in Switzerland. Facts and figures 2018. Bern: SBFI-Staatssekretariat für Bildung, Forschung und Innovation.

SERI. (2019). Job description of a carpenter. Der Bundesrat. Retrieved from https://www.becc.admin.ch/ becc/public/bvz/beruf/show/30513

Sheldon, G. (1992). Selbstselektion und Bildungsrenditen-Ökonometrische Untersuchungen an einem Mikro-Datensatz für die Schweiz [Self-selection and educational return econometric studies on a microdataset for Switzerland]. In D. Sadowski \& A. Timmesfeld (Eds), Ökonomie und Politik beruflicher BildungEuropäische Entwicklungen [Economics and politics of vocational education-European developments] (pp. 105-136). Berlin: Duncker \& Humblot.

Sheldon, G. (2005). Der berufsstrukturelle Wandel der Beschäftigung in der Schweiz 1970-2000: Ausmass, Ursachen und Folgen [The occupational structural change of employment in Switzerland 1970-2000: Extent, causes and consequences]. Neuchatel: Bundesamt für Statistik.

Spitz-Oener, A. (2006). Technical change, job tasks, and 
rising educational demands: Looking outside the wage structure. Journal of Labor Economics, 24, 235-270.

Stüber, H. (2016). Berufsspezifische Lebensentgelte. Qualifikation zahlt sich aus [Occupational life salaries. Qualification pays off]. Nürnberg: IAB-Kurzbericht.

Sullivan, P. (2010). Empirical evidence on occupation and industry specific human capital. Labour Economics, $17,567-580$.

Tåhlin, M. (2007). Skills and wages in European labour markets: Structure and change. In D. Gallie (Ed.), Employment regimes and the quality of work (pp. 35-76). New York, NY: Oxford University Press.

Tuor, S. N., \& Backes-Gellner, U. (2010). Risk-return trade-offs to different educational paths: Vocational, academic and mixed. International Journal of Manpower, 31, 495-519.

Verbeek, M., \& Nijman, T. (1992). Can cohort data be treated as genuine panel data? Empirical Economics, 17, 9-23.

Visser, J., \& Checchi, D. (2009). Inequality and the labor market: Unions. In S. Wiemer, B. Nolian, \& M. Timothy (Eds.), The Oxford handbook of economic inequality (pp. 230-256). New York, NY: Oxford University Press.

Weber, B. (1998). Bildungsrenditen in der SchweizEine empirische Untersuchung [Educational returns in Switzerland-An empirical study] (Working Paper). Universität Bern und Bundesamt für Wirtschaft und Arbeit.
Weber, B. A., \& Wolter, S. C. (1999). Wages and human capital: Evidence from Switzerland. In R. Asplund \& P. T. Pereira (Eds.), Returns to human capital in Europe: A literature review (pp. 325-350). Helsinki: ETLA.

Weeden, K. A. (2002). Why do some occupations pay more than others? Social closure and earnings inequality in the United States. American Journal of Sociology, 108, 55-101.

Williams, M. (2017). Occupational stratification in contemporary Britain: Occupational class and the wage structure in the wake of the great recession. Sociology, 51, 1299-1317.

Williams, M., \& Bol, T. (2018). Occupations and the wage structure: The role of occupational tasks in Britain. Research in Social Stratification and Mobility, 53, 16-25.

Wolter, S. C. (1994). Lohnt sich Bildung überhaupt? [Is education worthwhile at all?] (Economic Focus Report). Zurich: Union Bank of Switzerland.

Wolter, S. C., \& Weber, B. A. (1999). On the measurement of private rates of return to education. Jahrbücher für Nationalökonomie und Statistik, 218, 605-618.

Wolter, S. C., \& Weber, B. (2005). Bildungsrendite-Ein zentraler ökonomischer Indikator des Bildungswesens [Educational return: A key economic indicator of education]. Die Volkswirtschaft, 10, 38-42.

Wright, E. O. (2000). Class counts: Comparative studies in class analysis. Cambridge: Cambridge University Press.

\section{About the Authors}
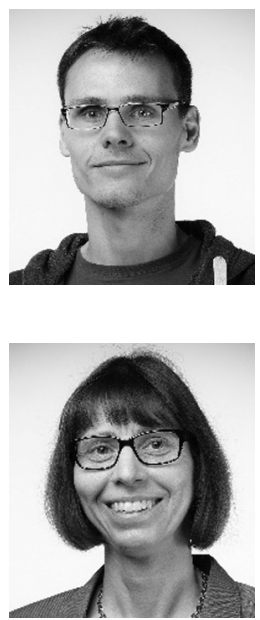

Fabian Sander is a Junior Researcher at the Swiss Federal Institute for Vocational Education and Training, where he works in the research area on strategic planning of VET. He is also a doctoral candidate at the University of Bern. He holds an MA in Sociology from the University of Leipzig. His research interests include social inequality, research methodology, and the economics of education.

Irene Kriesi is a Professor at the Swiss Federal Institute for Vocational Education and Training and co-head of the research area on strategic planning of VET. She holds a Doctorate in Sociology from the University of Zurich. Her research interests include educational trajectories, school-to-work transitions, occupational careers, and social inequality, with a specific focus on gender inequalities and vocational education and training. 


\section{Appendix}

Table A1. Occupational groups based on SBN2000.

\begin{tabular}{lll}
\hline 114 Gardening & 115 Forestry \& fishing & 211 Food production \\
\hline 212 Beverage \& luxury food & 241 Metal production & 242 Metalwork \\
\hline 243 Metal construction & 244 Machine and maintenance & 251 Electronic \& Electrotechnical \\
\hline 253 Vehicles \& machines & 261 Wood & 263 Paper production \\
\hline 271 Graphics & 281 Chemical & 291 Other occupations in work \& processing \\
\hline 311 Engineering & 321 Technicians & 331 Draftsmen \\
\hline 341 Technical experts & 351 Machine operators & 361 Information technology \\
\hline 411 Main construction trade & 412 Finishing trade & 511 Trade \& sales \\
\hline 523 Other services occup. & 531 Ground Transport & 533 Water \& air transport \\
\hline 541 Postal service \& telecomm. & 611 Hotel \& Catering service & 612 Domestic service \\
\hline 621 Cleaning services & 623 Personal services/hygiene & 711 Managers \\
\hline 721 Clerical \& administration & 731 Banking and insurance & 741 Security \\
\hline 751 Legal occupations & 811 Media & 813 Art \\
\hline 831 Social care & 832 Welfare & 865 Health care \\
\hline
\end{tabular}

Table A2. Model I-Results of (weighted) quasi-panel fixed effects regression.

\begin{tabular}{|c|c|c|}
\hline Effect of professional education (\%) & Coef. & Std. Err. \\
\hline \multicolumn{3}{|c|}{ Distributed fixed effect (number of years after graduation) } \\
\hline Year 1 & $0.053 * * *$ & $(0.015)$ \\
\hline Year 2 & $0.083^{* * *}$ & $(0.015)$ \\
\hline Year 3 & $0.114^{* * *}$ & $(0.016)$ \\
\hline Year 4 & $0.134 * * *$ & $(0.016)$ \\
\hline Year 5 & $0.140 * * *$ & $(0.017)$ \\
\hline Year 6 & $0.139 * * *$ & $(0.017)$ \\
\hline Year 7 & $0.143^{* * *}$ & $(0.016)$ \\
\hline Year 8 & $0.130 * * *$ & $(0.017)$ \\
\hline Year 9 & $0.125^{* * *}$ & $(0.016)$ \\
\hline Year 10 & $0.106 * * *$ & $(0.017)$ \\
\hline Year 11 & $0.128 * * *$ & $(0.016)$ \\
\hline Year 12 & $0.127^{* * *}$ & $(0.017)$ \\
\hline Year 13 & $0.128 * * *$ & $(0.017)$ \\
\hline Year 14 & $0.142 * * *$ & $(0.018)$ \\
\hline Year 15 & $0.177^{* * *}$ & (0.019) \\
\hline Year 16 & $0.165^{* * *}$ & $(0.020)$ \\
\hline Year 17 & $0.144 * * *$ & $(0.021)$ \\
\hline Year 18 & $0.141^{* * *}$ & $(0.023)$ \\
\hline Year 19 & $0.108 * * *$ & $(0.025)$ \\
\hline Year 20 & $0.125^{* * *}$ & $(0.026)$ \\
\hline Year 21 & $0.101^{* * *}$ & $(0.028)$ \\
\hline Year 22 & $0.104^{* * *}$ & $(0.030)$ \\
\hline Year 23 & 0.047 & $(0.039)$ \\
\hline Year 24 & $0.170 * * *$ & (0.059) \\
\hline
\end{tabular}


Table A2. (Cont.) Model I-Results of (weighted) quasi-panel fixed effects regression.

\begin{tabular}{|c|c|c|}
\hline Effect of professional education (\%) & Coef. & Std. Err. \\
\hline \multicolumn{3}{|l|}{ Calendar year $($ ref = 1991) } \\
\hline 1992 & $0.041^{* * *}$ & $(0.012)$ \\
\hline 1993 & $0.058 * * *$ & $(0.013)$ \\
\hline 1994 & $0.077 * * *$ & $(0.015)$ \\
\hline 1995 & $0.035^{*}$ & $(0.019)$ \\
\hline 1996 & $0.060 * * *$ & $(0.019)$ \\
\hline 1997 & 0.023 & $(0.025)$ \\
\hline 1998 & $0.047^{*}$ & $(0.025)$ \\
\hline 1999 & $0.068 * *$ & $(0.027)$ \\
\hline 2000 & $0.058^{*}$ & $(0.032)$ \\
\hline 2001 & $0.091 * * *$ & $(0.032)$ \\
\hline 2002 & $0.101^{* * *}$ & $(0.035)$ \\
\hline 2003 & $0.113^{* * *}$ & $(0.037)$ \\
\hline 2004 & $0.077^{*}$ & $(0.041)$ \\
\hline 2005 & 0.055 & $(0.045)$ \\
\hline 2006 & -0.005 & $(0.056)$ \\
\hline 2007 & 0.032 & $(0.054)$ \\
\hline 2008 & 0.012 & $(0.058)$ \\
\hline 2009 & 0.018 & $(0.062)$ \\
\hline 2010 & 0.043 & $(0.064)$ \\
\hline 2011 & 0.047 & $(0.066)$ \\
\hline 2012 & 0.031 & $(0.073)$ \\
\hline 2013 & 0.055 & $(0.073)$ \\
\hline 2014 & 0.014 & $(0.079)$ \\
\hline 2015 & 0.065 & $(0.078)$ \\
\hline Ratio labour demand (PE/VET) & $0.005^{* * *}$ & $(0.001)$ \\
\hline Average age & 0.005 & $(0.003)$ \\
\hline Constant & $10.99 * * *$ & $(0.096)$ \\
\hline F-Test & $140(72,241)$ & \\
\hline Observations & 314 & \\
\hline cohorts & 23 & \\
\hline
\end{tabular}

Notes: Standard errors in parentheses; ${ }^{* *} \mathrm{p}<0.01,{ }^{* *} \mathrm{p}<0.05, * \mathrm{p}<0.1$; Average panel length: 14 years, fixed effects panel regression weighted by the number of individuals per graduation cohort; $R^{2}$ is not shown in the table, because in a quasi-panel design it is not a reliable estimate.

Table A3. Results of (weighted) quasi-panel fixed effects regression.

\begin{tabular}{lll}
\hline Effect of professional education (\%) & Coef. & Std. Err. \\
\hline Average effect (all cohorts) & $0.107^{* * *}$ & $(0.014)$ \\
\hline Average effect until year15 after graduation (all cohorts) & $0.108^{* * *}$ & $(0.014)$ \\
\hline $\begin{array}{l}\text { Average effect for those observable for max. 15 years after graduation } \\
\text { (graduation cohorts 2001-2014) }\end{array}$ & $0.099^{* * *}$ & $(0.017)$ \\
\hline Average effect for cohorts observable for 24 years (graduation cohorts 1991-2000) & $0.114^{* * *}$ & $(0.022)$ \\
\hline
\end{tabular}

Notes: Standard errors in parentheses; ${ }^{* * *} \mathrm{p}<.01,{ }^{* *} \mathrm{p}<.05,{ }^{*} \mathrm{p}<0.1$; All models include the same controls as in Model in Table A2. 


\section{COGITATIO}

Table A4. Example of the similarity of Swiss and German occupations: Carpenter.

Tasks of Swiss Carpenters (SERI, 2019)

Tasks of German Carpenters (IAB/Berufenet, 2019)

Advising customers

Selling products

Preparation, manufacturing/production, repair of wood and wooden materials like:

- cabinets

- tables

- kitchens, wall and ceiling coverings,

wood implements for household

- carcasses

- doors

- windows

- sports equipment
Advising customers

Selling products

Preparation, processing/production, or repair of wood and wooden materials like:

- cabinets

- tables

- interior fittings

- seating

- doors

- windows 